\title{
Bilecik Doğal Florasından Toplanan Bituminaria bituminosa (L.) C.H. Stirtion Genotiplerinin Bazı Kalite Özelliklerinin Belirlenmesi
}

\author{
Hanife MUT ${ }^{1}$, Erdem GÜLÜMSER ${ }^{2 *}$, Medine ÇOPUR DOĞRUSÖZ ${ }^{3}$, Uğur BAŞARAN ${ }^{4}$ \\ Geliş / Received: 10/03/2020 \\ Revize / Revised: $22 / 04 / 2020$ \\ Kabul / Accepted: 26/04/2020
}

ÖZ

Türkiye'de 2019 verilerine göre 19 milyon büyükbaş hayvan birimi için gerekli olan kaliteli kaba yem miktarı 86 milyon ton olup, kaba yem açığı ise 55 milyon tondur. Diğer taraftan, Türkiye çok zengin bir floraya sahiptir ve 12476 (4.080 endemik) bitki türünü barındırmaktadır. Ancak, bu sayının 2030 yılında \% 34-42 düzeyinde azalacağı tahmin edilmektedir. Doğal florada bulunan bitkilerin korunması adına tanımlanmaları ve kültüre alınma olanaklarının tespiti de büyük önem taşımaktadır. Bu araştırma, Bilecik ili doğal florasından toplanan Bituminaria bituminosa (L.) C.H. Stirtion'un bazı kalite özelliklerinin belirlenmesi amacıyla yürütülmüştür. Bitkiler çiçeklenme döneminde ve 10 farklı lokasyondan toplanmıştır. Toplanan bitkilerde ham protein oranı, (HP), asit deterjanda çözünen lif (ADF), nötr deterjanda çözünen lif (NDF), potasyum (K), fosfor (P), kalsiyum (Ca), magnezyum (Mg), sindirilebilir kuru madde (SKM), kuru madde tüketimi (KMT), toplam sindirilebilir besin (TSB), nispi yem değeri (NYD) ve nispi yem kalitesi (NYK) değerleri incelenmiştir. Genotiplerin HP, NYD, NYK ve K değerleri sirasıyla \% 21.05-13.65, 139.48-95.79, 138.87-84.58 ve \% 3.30-2.07 arasında değişmiştir. Sonuç olarak, Bilecik ili doğal folarasından toplanan Bituminaria bituminosa genotiplerinin incelenen tüm kalite özellikleri açısından, kaba yem olarak hayvan ihtiyaçlarını karşılayacak düzeyde olduğu tespit edilmiştir.

\footnotetext{
"İletişim: hanife.mut@bilecik.edu.tr (https://orcid.org/0000-0002-5814-5275)

Tarla Bitkileri Bölümü, Bilecik Şeyh Edebali Üniversitesi, Gülümbe Kampüsü, Merkez, Bilecik

2*Sorumlu yazar iletişim: erdem.gulumser@ bilecik.edu.tr (https://orcid.org/0000-0001-6291-3831)

Tarla Bitkileri Bölümü, Bilecik Şeyh Edebali Üniversitesi, Gülümbe Kampüsü, Merkez, Bilecik

İletişim: medine.copur@yobu.edu.tr (https://orcid.org/0000-0002-9159-1699)

Tarla Bitkileri Bölümü, Yozgat Bozok Üniversitesi, Erdoğan Akdă̆ Kampüsü, Merkez, Yozgat

4iletişim: ugur.basaran@yobu.edu.tr (https://orcid.org/0000-0002-6644-5892)

Tarla Bitkileri Bölümü, Yozgat Bozok Üniversitesi, Erdoğan Akdă̆ Kampüsü, Merkez, Yozgat
} 


\title{
Determination on Some Quality Traits of Bituminaria bituminosa (L.) C.H. Stirtion Genotypes Collected from Natural Flora in Bilecik
}

\begin{abstract}
According to the 2019 data in Turkey, while the amount of roughage needed for 19 million livestock units is 86 million tons, the forage deficit is 55 million tons. On the other hand, Turkey has a very rich flora and 12476 (4.080 endemic) contains plant species. But, it's estimated that this number will decrease in the level of 34-42\% in the 2030 year. In order to protect the plants in the natural flora, it is of great importance to characterize of these plants and investigate the possibilities for cultivating. The aim of the study was to determine some quality traits of Bituminaria bituminosa (L.) C.H. Stirtion collected from ten different locations in the natural flora of Bilecik province. Plants were collected at the flowering stage and investigated for crude protein ratio (CP), acid detergent fiber (ADF), neutral detergent fiber (NDF), potassium (K), phosphorus (P), calcium (Ca), magnesium $(\mathrm{Mg})$, digestible dry matter (DDM), dry matter intake (DMI), total digestible nutrients (TDN), relative feed value (RFV) and relative feed quality (RFQ) values. CP, RFV, RFQ and K values of genotypes ranged between 21.05$13.65 \%, 139.48-95.79,138.87-84.58$ and $3.30-2.07 \%$, respectively. As a result, it has been determined that Bituminaria bituminosa genotypes collected from the natural flora of Bilecik province have been sufficient for animal feeding as roughage in terms of all the quality traits.
\end{abstract}

Keywords-Bituminaria bituminosa, Genotype, Forage quality, Natural flora. 


\section{GİRiş}

Türkiye hayvansal ürünlerin üretiminde, veriminde ve doğal olarak tüketiminde halen istenilen seviyeye gelememiş̧ir. Bunun en önemli nedenlerinden bir tanesi yemin ucuz ve kolay temin edilememesidir. Türkiye'de yerel üretim miktarları dikkate alındığında yüksek düzeyde kesif ve kaba yem açığı bulunmaktadır. Bu sorunun çözülmesi için, önemli kaba yem kaynaklarından biri olan çayır-meraların bir an önce ıslah edilmesi ve uygun şartlarda kullanılması gereklidir. Diğer taraftan tarla tarımı içerisinde yetiştirilen yem bitkileri üretimi ise oldukça azdır. Türkiye'de 2019 verilerine göre 19 milyon büyükbaş hayvan birimi için gerekli olan kaliteli kaba yem miktarı 86 milyon ton civarındadır. Mevcut üretim ise bu miktarın sadece \% 35.7'lik kısmını karşılayabilmektedir. Dolayısıyla ülkede 55 milyon ton kadar kaba yem açı̆̆ı bulunmaktadır [1].

Bir ülkenin sahip olduğu biyolojik çeşitliliğin yaşamsal ölçüde önemli olduğu gerçeği bugün tüm dünya tarafından kabul edilen bir olgudur. Türkiye bu bakımdan kıskanılacak bir zenginliğe sahiptir [2]. Nitekim sahip olduğu 78 milyon ha alanda 12.476 (4.080'i endemik) bitki türü barındırmaktadır. Ancak artan dünya nüfusu ile birlikte yapılaşma, sanayileşme ve iklim değişikliği gibi etmenler bu türler üzerine olumsuz etkiler yaratmaktadır. Bu konu üzerinde hazırlanan senaryolar Türkiye'de 2000 yılında $\% 45$ düzeyinde olan bitkisel genetik potansiyelin, 2030 yılında \% 34-42 düzeylere kadar düşebileceğini göstermektedir [3].

Baklagiller familyasında yer alan Bituminaria bituminosa (L.) C.H. Stirtion çok yıllık bir türdür. Anavatanı Akdeniz olan bitki Türkiye, Güney Avrupa, Kırım, Batı Suriye, Kıbrıs, Kafkasya, İsrail, Kuzey Afrika'da ve Portekiz, İspanya gibi ülkelerin doğal vejetasyonunda da geniş bir yayllım göstermektedir. Halk arasında katran yoncası, demir otu, katranlı yaban üçgülü gibi isimlerle de bilinen bitkinin tarımı sadece Kanarya Adaları ve Fas'ta yapılmaktadır. Ülkemizde tarımı yapılmayan bitki, Adana, Antalya, Çanakkale, Hatay, İstanbul, İzmir, Muğla, Samsun, Sinop, Tekirdağ, Trabzon, Yozgat ve Zonguldak doğal florasında yetişmektedir. Genel olarak açık yerlerde, yol kenarlarında, üst toprak tabakası kaybolmuş alanlarda, erozyona açık yamaçlarda, ağaçlık ve ormanlık alanlarda ve 4.7 ile 8.5 arasındaki pH'da yetişebilmektedir [4].

Bituminaria bituminosa'nın Medicago arborea'dan daha fazla protein ve sindirilebilir enerji içerdiği, çalı formundaki bir baklagil olan Chamaecytisus palmensis ile benzer kimyasal içeriğe sahip olduğu belirlenmiş̧ir. [5]. Bitki üzerinde yapılan çalışmalarda; ham protein, ADF ve NDF oranları sırasıyla \% 20.4$10.3, \%$ 41.9-23.8 ve \% 56.3-38.0 arasında değişmiştir. Bilecik ilinin doğal vejetasyonunda da geniş yaylım gösteren bitki [2], kaba yem kaynaklarının bulunmadığı sıcak ve kurak yaz aylarında (Haziran-Ağustos) yeşil kalabilmektedir $[6,7,8,9,10]$.

$\mathrm{Bu}$ çalışmada Bilecik doğal florasının 10 farklı lokasyonundan çiçeklenme döneminde toplanan Bituminaria bituminosa (L.) C.H. Stirtion genotiplerinde bazı kalite özelliklerinin belirlenmesi amaçlanmıştır.

\section{MATERYAL VE METOT}

Bilecik ilinden 2019 yılının Ağustos ayında toplanan Bituminaria bituminosa (L.) C.H. Stirtion genotipleri " $B b$ " bitkisel materyal olarak kullanılmıştır (Tablo 1). Bitkilerin toplandığı duraklar arasındaki mesafe en az 8 km olup [11], duraklara ait yükseklik ve koordinat bilgileri GPS ile ölçülerek kaydedilmiştir. Yol kenarlarında fazlaca bulunan bitkinin toplama işlemi ilk etapta yola yakın yerlerde, daha sonra yola uzak alanlarda yapılmıştır. Bitkiler araziden çiçeklenme döneminde toplanmıştır. Genotipler her duraktan 3 bitki olacak şekilde toplanmış olup, bu 3 genotipin ortalaması ise lokasyonu temsil etmiştir.

Genotiplerin toplandığı Bilecik ilinin uzun yıllar ortalama yağış toplamı $457.1 \mathrm{~mm}$ iken, 2019 yılında $1415.1 \mathrm{~mm}$ olmuştur. Uzun yıllar sıcaklık ortalaması $12.50{ }^{\circ} \mathrm{C}, 2019$ yllında $13.13{ }^{\circ} \mathrm{C}$ olarak tespit edilmiştir. İlin uzun yıllar ve 2019 döneminde ortalama nispi nem değerleri ise sırasıyla \% 67.40 ve \% 69.27 olmuştur [12].

Doğal floradan toplanan ve kese kâğıdına konulan $B b$ örnekleri Bilecik Şeyh Edebali Üniversitesi, Ziraat ve Doğa Bilimleri Fakültesi, Tarla Bitkileri Bölümü Laboratuvarına getirilmiştir. Daha sonra bu örnekler sabit ağırlığa gelene kadar $60^{\circ} \mathrm{C}$ 'de etüvde kurutulmuş ve elek çapı $1 \mathrm{~mm}$ olan değirmende öğütülerek analize hazır hale getirilmiştir. Öğütülen örneklerin ham protein, $\mathrm{ADF}, \mathrm{NDF}, \mathrm{K}, \mathrm{Ca}, \mathrm{P}$ ve $\mathrm{Mg}$ oranları Yozgat Bozok Üniversitesi, Ziraat Fakültesi, Tarla Bitkileri Bölümü Laboratuvarında bulunan Near Infrared Reflectance Spectroscopy (Foss 6500) cihazıyla IC-0904FE paket programı kullanılarak belirlenmiştir [13]. Çalışmada ADF 
ve NDF değerlerinden faydalanılarak genotiplere ait bazı kalite standartları belirlenmiştir. $\mathrm{Bu}$ standartların belirlenmesinde ise Rohweder ve ark. (1978)'nın [14] belirlemiş oldukları formüller kullanılmıştır.

Sindirilebilir Kuru Madde (SKM): (88.9-(0.779*\%ADF)

Toplam Sindirilebilir Besin (TSB): (96.35-(ADF*1.15))

Kuru Madde Tüketimi (KMT): (120/NDF)

Nispi Yem Değeri (NYD): (\%SKM * \%KMT) /1.29

Nispi Yem Kalitesi (NYK): (\%KMT*\%TSB)/1.23

Tablo 1. Bituminaria bituminosa genotiplerinin toplandığı yerlere ait coğrafi bilgiler

\begin{tabular}{|c|c|c|c|c|}
\hline \multirow{2}{*}{ Toplama yeri } & \multirow{2}{*}{ Kısa ismi } & \multicolumn{2}{|c|}{ Koordinatlar } & \multirow{2}{*}{ Yükseklik (m) } \\
\hline & & Kuzey & Doğu & \\
\hline Yakacık & Yk & $40^{\circ} 4^{\prime} 50.65^{\prime \prime}$ & $30^{\circ} 18^{\prime} 52.74 "$ & 162 \\
\hline Tuzaklı & $\mathrm{Tu}$ & $40^{\circ} 6^{\prime} 12.83^{\prime \prime}$ & $30^{\circ} 14^{\prime} 10.08 "$ & 185 \\
\hline Akçasu & As & $40^{\circ} 5^{\prime} 27.21^{\prime \prime}$ & $30^{\circ} 18^{\prime} 9.49^{\prime \prime}$ & 326 \\
\hline Abbaslık & $\mathrm{Ab}$ & $40^{\circ} 7^{\prime} 25.50^{\prime \prime}$ & $29^{\circ} 58^{\prime} 40^{\prime \prime}$ & 432 \\
\hline Küre & $\mathrm{Kr}$ & $40^{\circ} 4^{\prime} 48.02^{\prime \prime}$ & $30^{\circ} 7^{\prime} 47.16^{\prime \prime}$ & 450 \\
\hline Söğüt & St & $40^{\circ} 1^{\prime} 29.55^{\prime \prime}$ & $30^{\circ} 9^{\prime} 49.05^{\prime \prime}$ & 645 \\
\hline Kepen & $\mathrm{Ke}$ & $39^{\circ} 59^{\prime} 59.72^{\prime \prime}$ & $30^{\circ} 8^{\prime} 10.72^{\prime \prime}$ & 778 \\
\hline Ormangözle & Og & $39^{\circ} 53^{\prime} 20.21^{\prime \prime}$ & $29^{\circ} 55^{\prime} 21.16^{\prime \prime}$ & 800 \\
\hline Esemen & Es & $40^{\circ} 2^{\prime} 51.51^{\prime \prime}$ & $29^{\circ} 53^{\prime} 54.09^{\prime \prime}$ & 1010 \\
\hline Darıdere & Dd & $39^{\circ} 48^{\prime} 25.46^{\prime \prime}$ & $29^{\circ} 58^{\prime} 10.00^{\prime \prime}$ & 1126 \\
\hline
\end{tabular}

Araştırmadan elde edilen verilerin analizi SPSS 21.0 paket programı, biplot analizi ve grafiği ise PASW (18) İstatistik Veri Temel bileşen analizi yardımıyla (PCA) yapılmıştır.

\section{BULGULAR VE TARTIŞMA}

Bilecik ili doğal florasından toplanan 10 adat adet $B b$ genotiplerine ait ham protein oranı (HP), asit deterjanda çözünen lif (ADF), nötr deterjanda çözünen lif (NDF), potasyum (K), fosfor $(\mathrm{P})$, kalsiyum (Ca) ve magnezyum (Mg) oranları Tablo 2'de verilmiştir.

Tablo 2. Bituminaria bituminosa genotiplerine ait $\mathrm{HPO}, \mathrm{ADF}, \mathrm{NDF}, \mathrm{K}, \mathrm{P}, \mathrm{Ca}$ ve Mg oranları (\%).

\begin{tabular}{|c|c|c|c|c|c|c|c|}
\hline Genotipler & HP & ADF & NDF & $\mathbf{K}$ & $\mathbf{P}$ & $\mathbf{C a}$ & Mg \\
\hline Yakacık & 13.65 & 43.51 & 53.41 & 2.43 & 0.18 & 1.29 & 0.29 \\
\hline Tuzaklı & 13.93 & 39.48 & 54.63 & 2.76 & 0.26 & 0.93 & 0.21 \\
\hline Akçasu & 18.32 & 32.07 & 47.16 & 2.27 & 0.22 & 1.23 & 0.46 \\
\hline Abbaslik & 14.55 & 36.47 & 52.79 & 2.07 & 0.33 & 1.29 & 0.32 \\
\hline Küre & 17.16 & 35.70 & 51.69 & 2.82 & 0.25 & 1.05 & 0.30 \\
\hline Söğüt & 21.05 & 29.13 & 44.15 & 3.30 & 0.34 & 1.19 & 0.45 \\
\hline Kepen & 19.53 & 31.91 & 45.68 & 2.74 & 0.30 & 1.27 & 0.43 \\
\hline Ormangözle & 18.09 & 34.02 & 50.13 & 2.87 & 0.25 & 1.27 & 0.32 \\
\hline Esemen & 17.12 & 34.98 & 51.35 & 3.17 & 0.33 & 1.04 & 0.32 \\
\hline Darıdere & 19.51 & 32.95 & 48.26 & 3.20 & 0.28 & 1.00 & 0.30 \\
\hline Ortalama & 17.29 & 35.02 & 49.93 & 2.76 & 0.27 & 1.16 & 0.34 \\
\hline En düşüik & 12.85 & 27.85 & 43.03 & 2.01 & 0.18 & 0.91 & 0.20 \\
\hline En yüksek & 21.14 & 44.72 & 57.01 & 3.40 & 0.36 & 1.41 & 0.47 \\
\hline Standart sapma & 2.55 & 4.48 & 3.91 & 0.40 & 0.05 & 0.22 & 0.07 \\
\hline$\% \mathrm{VK}$ & 14.75 & 12.79 & 7.83 & 14.49 & 18.52 & 18.97 & 20.59 \\
\hline
\end{tabular}

HP: Ham protein oranı; ADF: Asit deterjanda çözünen lif; NDF: Nötr deterjanda çözünen lif; K: Potasyum, P: Fosfor; Ca: Kalsiyum; Mg: Magnezyum

En yüksek ham protein oranı \% 21.05 ile Söğüt, en düşük ise \% 13.65 ile Yakacık lokasyonundan toplanan genotiplerde belirlenmiştir (Tablo 2). Genotiplerin ham protein oranına ait varyasyon katsayısı (VK) 
\% 14.75 olarak belirlenmiştir. Gülümser (2011) [15] Karadeniz bölgesinden topladığı $B b$ genotiplerinde ham protein oranının \% 24.60-13.28 arasında değiştiğini bildirmiştir. Bu bulgu, bu çalışma sonucunda elde edilen sonuçla uyumludur.

Doğal floradan toplanan $B b$ genotiplerinin ADF ve NDF oranları sırasıyla \% 43.51-29.13 ve \% 54.6344.15 arasında değişmiş, ortalama değerleri ise sırasıyla \% 35.02 ve \% 49.93 olarak belirlenmiştir (Tablo 2). VK değeri ise ADF için \% 12.79, NDF için \% 7.83 olmuştur. Birçok araştırıcı tarafından yapılan çalışmada $B b$ 'nin ADF ve NDF oranının sırasıyla \% 38.8-21.9 ve \% 56.30-25.00 arasında değiştiği belirlenmiştir $[5,8,9,10,15]$. Çalışmalar arasındaki farklılıkların, incelenen materyallerin gelişme dönemi ile toplama alanlarındaki iklim ve toprak faktörlerinden kaynaklandığı tahmin edilmektedir.

En yüksek K içeriği \% 3.30 ile Sögüut, en düşük ise \% 2.07 ile Abbaslık lokasyonundan toplanan genotiplerde belirlenmiştir. P, Ca ve Mg oranları ise sirasıyla \% 0.33-0.18, \% 1.29-0.93 ve \% 0.46-0.29 arasında değişmiştir. Makro besin elementleri arasında en yüksek VK değeri ise \% 20.59 ile Mg oranında tespit edilmiştir (Tablo 2). Geviş getiren hayvanlar için yemlerde $\mathrm{K}$ içeriğinin \% 0.8 , P içeriğinin $\% 0.21$, Ca içeriğinin \% 0.3 ve $\mathrm{Mg}$ içeriğinin ise \% 0.1-0.2 arasında bulunması gerekmektedir [16, 17]. Buna göre, incelenen tüm genotiplerin söz konusu elementler için hayvan besleme açısından istenen değerlerin üstünde olduğu görülmektedir. Bu çalışmaya benzer şekilde, Gülümser (2011) [15] Samsun, Sinop, Ordu ve Zonguldak illerinin farklı yerlerinden toplanan $B b$ genotiplerinde $\mathrm{K}, \mathrm{P}, \mathrm{Ca}$ ve $\mathrm{Mg}$ içeriklerinin sirasıyla \% 2.15-1.11, \% 0.40-0.26, \% 2.17-1.03 ve \% 2.2-0.63 arasında değiştiğini bildirmiştir. Sonuçların, bu çalışma ile uyumlu olduğu görülmektedir.

Bilecik ilinin farklı yerlerinden toplanan $B b$ genotiperinin sindirilebilir kuru madde (SKM), toplam sindirilebilir besin (TSB), kuru madde tüketimi (KMT), nispi yem değeri (NYD) ve nispi yem kalitesi (NYK) verileri Tablo 3'de verilmiştir.

Tablo 3. $B b$ genotiplerine ait SKM, TSB, KMT (\%), NYD ve NYK değerleri

\begin{tabular}{|c|c|c|c|c|c|}
\hline Genotipler & SKM & TSB & KMT & NYD & NYK \\
\hline Yakacık & 55.01 & 46.32 & 2.25 & 95.79 & 84.58 \\
\hline Tuzaklı & 58.14 & 50.94 & 2.19 & 99.02 & 90.98 \\
\hline Akçasu & 63.91 & 59.47 & 2.55 & 126.63 & 123.52 \\
\hline Abbaslik & 60.49 & 54.41 & 2.27 & 106.75 & 100.74 \\
\hline Küre & 61.09 & 55.30 & 2.33 & 110.85 & 105.31 \\
\hline Söğüt & 66.21 & 62.85 & 2.71 & 139.48 & 138.87 \\
\hline Kepen & 64.03 & 59.65 & 2.63 & 130.35 & 127.29 \\
\hline Ormangözle & 62.40 & 57.22 & 2.39 & 116.03 & 111.72 \\
\hline Esemen & 61.65 & 56.12 & 2.33 & 111.70 & 106.66 \\
\hline Darıdere & 63.23 & 58.45 & 2.49 & 122.05 & 118.38 \\
\hline Ortalama & 61.62 & 56.07 & 2.41 & 118.10 & 113.72 \\
\hline En düşük & 54.07 & 44.93 & 2.10 & 96.40 & 85.94 \\
\hline En yüksek & 67.20 & 64.32 & 2.79 & 139.80 & 141.50 \\
\hline Standart sapma & 3.49 & 5.15 & 0.19 & 14.73 & 17.65 \\
\hline$\% \mathrm{VK}$ & 5.66 & 9.18 & 7.88 & 12.47 & 15.52 \\
\hline
\end{tabular}

SKM: Sindirilebilir kuru madde; TSB: Toplam sindirilebilir besin; KMT: Kuru madde tüketimi; NYD: Nispi yem değeri; NYK: Nispi yem kalitesi

En yüksek SKM değeri \% 64.03 ile Kepen, en düşük ise \% 55.01 ile Yakacık lokasyonundan toplanan bitkilerde tespit edilmiştir. Bu özelliğe ait VK oranı ise \% 5.66 olarak belirlenmiştir. Yapılan çalışmalarda yonca bitkisindeki SKM oranının \% 63.17-60.62 [18], mürdümük bitkisinde ise \% 66.5-62.1 arasında değiştiği belirlenmiştir [19]. Bu durum $B b$ genotiplerinin sindirilme değerinin yoncaya benzer olduğunu göstermektedir. $B b$ genotiplerinde TSB oranı \% 46.32 (Yakacık) - 62.85 (Söğüt) arasında değişmiş ve ortalama \% 56.07 olarak belirlenmiştir. En yüksek KMT Söğüt (\% 2.71 ), en düşük ise Tuzaklı (\% 2.19) lokasyonlarına ait genotiplerde belirlenmiştir. Genotipler arasında KMT değeri ortalama \% 2.41 iken, VK ise \% 7.88 olarak tespit edilmiştir.

NYD ve NYK değerleri ADF ve NDF oranları kullanılarak hesaplanan ve yemin kalitesini rakamsal olarak gösteren bir ölçüdür [20]. En yüksek NYD ve NYK değeri Söğüt (sırasıyla; 139.48 ve 138.87), en düşük Yakacık (sırasıyla; 95.79 ve 84.58) lokasyonundan toplanan $B b$ genotiplerinde tespit edilmiştir. Genotiplerin 
ortalama NYD ve NYK ile VK oranları ise sırasıyla 118.10-113.72 ve \% 12.47-15.52 olmuştur (Tablo 3). NYD yem bitkileri pazar fiyatlarının belirlenmesi amacıyla kullanılan 6 kalite sınıfına ayrılmış rakamsal bir ölçüttür. Buna göre, NYD 151'den büyükse başlangıç sınıfı, 125-151 arasında ise 1. sınıf, 103-124 arasında ise 2. sınıf, 87-102 arasında ise 3. sınıf, 75-86 ise 4. sınıf ve 75' den küçük olduğunda ise 5. sınıf olarak kabul edilmiştir [14]. NYK ise 4 sınıfta toplanmış olup, 140'dan büyükse çok iyi, 110-139 arasında ise iyi, 90-109 arasında ise orta ve 75'den az ise kötü sınıf olarak kabul edilmektedir [21]. Çalışmada genotiplerin NYD değerleri 1. 2. ve 3. sınıfta yer alırken, NYK değeri ise orta ve iyi kalite sınıfı arasında değişmiştir (Tablo 3). Gülümser ve ark. (2020) [22] doğal floradan topladıkları ak taş yoncalarının NYD değerinin 147.58 ile 93.44 arasında değiştiğini bildirmiştir.

Şekil 1'de $B b$ genotipleri ile kalite özellikleri arasındaki interaksiyonu gösteren biplot grafiği verilmiştir. Grafikte, ana bileşen 1 (\% 73.44) ve ana bileşen 2 (\% 17.45) değerlerinin toplamı \% 90.89 olmuştur. Firıncıoğlu ve ark. (2012) [23] ile Sayar ve Han (2015) [24] ana bileşenlerin değerinin yüksek olmasını grafiğin daha güvenli yorumlanması açısından önem teşkil ettiğini ve grafik üzerinde genotiplerin etkisinin daha yüksek olduğunu bildirmektedir. Şekil 2 incelendiğinde, tüm kalite kriteleri açısından Söğüt (St), Darıdere (Dd), Akçasu (As) ve Kepen $(\mathrm{Ke})$ genotipleri öne çıkmıştır. Diğer taraftan ADF ve NDF oranları aynı grupta yer almış ve oluşan bu grubun içerisinde ise Tuzaklı (Tu) ve Yakacık (Yk) genotipleri yer almıştır.

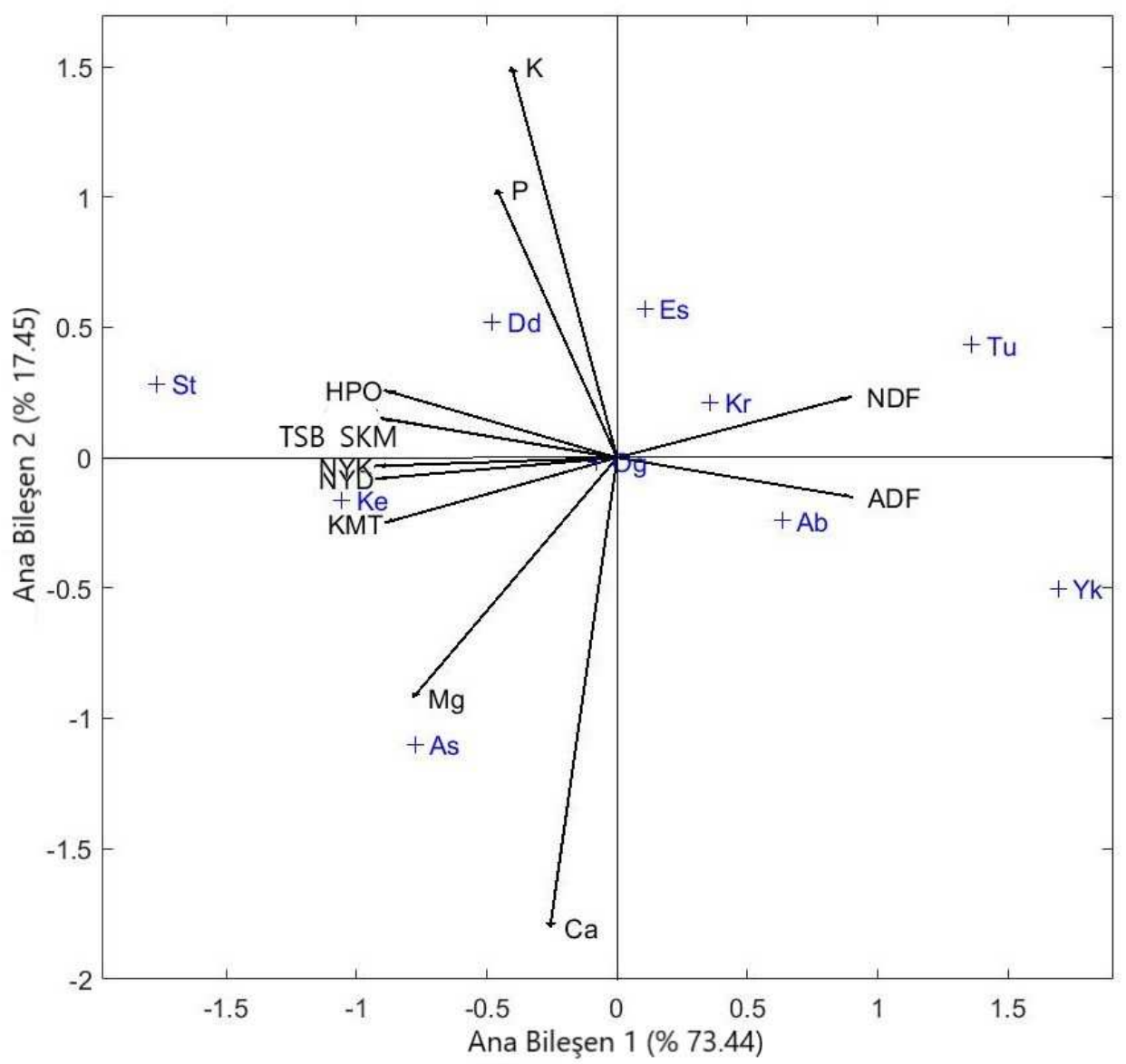

Şekil 1. Bituminaria bituminosa genotiplerinin iki ana bileşenine dayalı dağılım grafiği 


\section{SONUÇ}

Bilecik ili doğal florasından toplanan $B b$ genotiplerinin kalite özellikleri incelenmiş ve genotipler arasında kalite özellikleri bakımından farklılıklar ile geniş bir varyasyon tespit edilmiştir. Bu durum bu bitkilerde ileride yapılacak olan ıslah çalışmalarına 1şık tutacak niteliktedir. Zira ülkemizde ve bölgemizde mevcut hayvanların beslenmesi açısından kaba yem açı̆̆ının kapatılmasında alternatif yem bitkilerine yönelme zorunluluğu varken, günümüzde doğal çeşitliliğin tehlike altında olduğu da yadsınamaz bir gerçektir. İncelenen $B b$ bitkilerinde ham protein ile makro besin içeriklerinin yeterli, yemin kalitesini ortaya koyan standartlarının ise iyi seviyede olduğu tespit edilmiştir. Bu itibarla farklı lokasyondan toplanan Bituminaria bituminosa'nın hayvan beslenmesinde kullanılabileceği belirlenmiştir.

\section{KAYNAKLAR}

[1] Acar, Z., Tan, M., Ayan, İ., Önal Aşçı, Ö., Mut, H., Başaran, U., Gülümser, E., Can, M \& Kaymak, G. (2020). Türkiye'de Yem Bitkileri Tarımının Durumu ve Geliştirme Olanakları. Türkiye Ziraat Mühendisleri IX. Teknik Kongresi. 13-17 Ocak, Ankara

[2] Ocak A., Öztürk, D., \& Kara, İ. (2017). Bilecik Florası. Bilecik Şeyh Edebali Üniversitesi Yayınları, Bilecik, $1135 \mathrm{~s}$.

[3] Alkamade, R., Oorschot, M., Miles, L., Nellemann, C., Bakkenes, M., \& Brink, B. (2009). A framework to investigate options for reducing global terrestrial biodiversity loss. Ecosystems. www.pbl.nl/en/publications/2009/GLOBO3-A-Framework-toinvestigate-options-for-reducing-globalterrestrial-biodiversity-loss.html. (Ziyaret tarihi: 05.09.2019).

[4] Davis, P.H. (1965). Flora of Turkey And The East Aegean Islands. Edinburgh University Press, Edinburgh, $567 \mathrm{~s}$.

[5] Ventura, M.R., Flores, M.P., \& Castanon, J.I.R. (1999). Nutritive value of forage shrubs: Bituminaria bituminosa. Acacia salicina and Medicago arborea. In 'Cahiers Options Mediterraneennes. 39, 171-173.

[6] Ventura, M.R., Castanon, J.I.R., Pieltain, M.C., \& Flores, M.P. (2004). Nutritive value of forage shrubs: Bituminaria bituminosa. Rumexlunaria. Acacia salicina. Cassia sturtii and Adenocarpus foliosus. Small Rumin. Researech, 52, 13-18.

[7] Ventura, M.R., Castanon, J.I.R., \& Mendez, P. (2009). Effect of season on tedera (Bituminaria bituminosa) intake by goats. Animal Feed Science and Technology, 153, (3-4), 314-319.

[8] Álvarez, S., Méndez, P., Díaz, C., \& Fresno, M. (2004). Ingestión. composición química ydigestibilidad in vivo de tedera (Bituminaria bituminosa (L.) Stirton). In 'XLIVreunión científica de la S.E.E.P. pastos y ganadería extensiva', Salamanca pp. 337-340.

[9] Sternberg, M., Gishri, N., \& Mabjeesh, S.J. (2006). Effects of grazing on Bituminaria bituminosa (L.) Stirton: a potential forage crop in Mediterranean grasslands. Journal of Agronomy and Crop Science, 192, 399-407.

[10] Pecetti, L., Tava, A., Pagnotta, MA., \& Russi, L. (2007). Variation in forage quality and chemical composition among Italian accessions of Bituminaria bituminosa (L.) Stirt. Journal of the Science of Food and Agriculture, 87, 985-991.

[11] Tan, A. (1992). Türkiye'deki Bitkisel Çeşitlilik ve Bitki Genetik Kaynakları. Anadolu Dergisi, 2, 50-64.

[12] Anonymous, 2019. https://mgm.gov.tr/?il=Bilecik (Ziyaret tarihi: 12.09.2019).

[13] Straks, P.J., Samuel, W.C., \& William, A.P. (2004). Determination of Forage Chemical Composition Using Remote Sensing. Journal of Range Management, 57, 635-640. 
[14] Rohweder, D.A., Barnes, R.F., \& Jorgensen, N. (1978). Proposed hay grading standards based on laboratory analyses for evaluating quality. Journal of Animal Science, 47, (3), 747-759.

[15] Gülümser, E. (2011). Orta Karadeniz Bölgesinde Doğal Olarak Yetişen Bituminaria bituminosa L. (Syn. Psoralea bituminosa L.) Bitkisinin Tanımlanması ve Tarımsal Özelliklerinin Araştırılması. Yüksek Lisans Tezi, Ondokuz Mayıs Üniversitesi, Fen Bilimleri Enstitüsü, Samsun.

[16] Tejeda, R., Mcdowell, L.R., Martin, F.G., \& Concard, J.H. (1985). Mineral element analyses of various tropical forages in Guattamala and their relationship to soil concentrations. Grassland and Forage Abstract, 71(8).

[17] Kidambi, S.P., Matches, A.G., \& Grigs, T.C. (1989). Variability for Ca. Mg. K. Cu. Zn and K/(Ca+Mg) ratio 3 wheat grasses and on the southern sainfoin high plains. Journal Range Management, 42, 316 - 322.

[18] Canbolat, Ö., Kalkan, H., Karaman, S., \& Filya, İ. (2010). Üzüm Silajının Yonca Silajında Karbonhidrat Kaynağı olarak Kullanılma Olanakları. Kafkas Üniversitesi Veterinerlik Fakültesi Dergisi, 16, (2), $269-276$.

[19] Basaran, U., Mut, H., Asçı, Ö. Ö., Acar, Z., \& Ayan, İ. (2011). Variability forage Quality of Turkısh Grass Pea (Lathyrus Sativus L.) Landraces. Turkish Journal of Field Crops, 16, (1), 9-11.

[20] Yavuz, M., İptas, S., Ayhan, V., \& Karadağ, Y. (2009). Yembitkilerinde Kalite ve Yembitkilerinden Kaynaklanan Besleme Bozuklukları. Ofset Hazırlık Emre Basımevi, İzmir, 163-172.

[21] Marten, G.C., Buxton, D.R., \& Barnes, R.F. (1988). Feeding value (forage quality). Madison, Wisconsin, USA, 463-492.

[22] Gülümser, E., Mut, H., Çopur Doğrusöz, M., \& Başaran, U. (2020). Doğal Floradan Toplanan Aktaş Yoncalarının (Melilotus alba Desr.) Bazı Kalite Özellikleri. Türk Tarım - Gida Bilim ve Teknoloji Dergisi, 8, (2), 324-328.

[23] Fırıncıoğlu, H.K., Ünal, S., Pank, Z., \& Beniwal, S.P.S. (2012). Growth and development of narbon vetch (Vicia narbonensis L.) genotypes in the semi-arid central Turkey. Spanish Journal of Agricultural Research, 10, (2), 430-442.

[24] Sayar, M.S., \& Han, Y. (2015). Mürdümük (Lathyrus sativus L.) Hatlarının tohum verimi ve verim komponentlerinin belirlenmesi ve GGE biplot analiz yöntemiyle değerlendirilmesi. Tarım Bilimleri Dergisi, 21, (1), 78-92. 